\title{
Neuroblastoma and Fetal Exposure to Phenytoin in a Child Without Dysmorphic Features
}

\author{
S. Al-Shammri, A. Guberman and E. Hsu
}

\begin{abstract}
Despite the fact that the teratogenic effects of phenytoin have been suggested in several case reports, the evidence for a possible oncogenic potential of phenytoin has not been widely recognized. Recently, neuroblastoma as well as other neuroectodermal and non-ectodermal tumors has been seen in several children exposed to phenytoin prenatally. Previous cases have been almost uniformly associated with the features of "fetal hydantoin syndrome" and none have been developmentally normal. We report a developmentally-normal boy of $2 \frac{1}{2}$ years with an abdominal neuroblastoma whose mother had been on phenytoin (as well as carbamazepine) throughout gestation. We review the various neoplasms which have been reported in the offspring of mothers receiving phenytoin.
\end{abstract}

RÉSUMÉ: Neuroblastome et exposition fétale à la phénitoïne chez un enfant sans trait dysmorphique. En dépit du fait que les effets tératogènes de la phénitoïne ont été suggérés dans plusieurs observations de cas, les indications que la phénitoïne a possiblement un potentiel oncogène n'ont pas été largement reconnues. Récemment, le neuroblastome ainsi que d'autres tumeurs d'origine neuro-ectodermique et non-ectodermique ont été observées chez plusieurs enfants exposés à la phénitoïne à la période prénatale. Les cas antérieurs ont été presque tous associés aux manifestations du "syndrome fétal de l'hydantoïne" et aucun n'a eu un développement normal. Nous rapportons le cas d'un garçon de deux ans et demi dont le développement était normal et qui avait un neuroblastome abdominal. Sa mère avait pris de la phénitoïne (ainsi que de la carbamazépine) pendant toute la grossesse. Nous revoyons les différents néoplasmes qui ont été rapportés chez les enfants de mères recevant de la phénitoïne.

Can.J. Neurol. Sci. 1992; 19:243-245

Neuroblastoma, a neural crest tumor, has been reported recently in the offspring of epileptic mothers who were exposed to phenytoin and other antiepileptic drugs. ${ }^{1-6}$ Phenytoin was incriminated as the most likely oncogenic agent in most cases because all the children who developed a neuroblastoma were also affected by a combination of malformations which has been termed the fetal hydantoin syndrome (FHS). ${ }^{5}$ It is now recognized however that a similar pattern of malformations or anomalies can occur with maternal use of other antiepileptic drugs besides phenytoin. ${ }^{7}$ This is the first report of a neuroblastoma in a developmentally-normal child who was exposed prenatally to phenytoin (as well as carbamazepine).

\section{CaSe Report}

A $21 / 2$ year-old boy was admitted to the Children's Hospital of Eastern Ontario for the investigation of an abdominal mass. He had also been febrile and had a recent otitis media. His mother had been on phenytoin $300-350 \mathrm{mg} /$ day throughout the gestation and for 8 years prior for idiopathic epilepsy with generalized tonic-clonic and complex partial seizures. The one phenytoin level obtained during gestation was $5 \pi \mathrm{mol} / \mathrm{ml}$. She had also been taking carbamazepine $800-1000 \mathrm{mg} /$ day (level $19 \pi \mathrm{mol} / \mathrm{ml}$ ) throughout the pregnancy. She was not exposed to alcohol and tobacco during gestation. Seizures were completely controlled during pregnancy. The child's birth and developmental mile- stones were normal. There were no detectable congenital malformations or anomalies.

Examination revealed a normocephalic child with no dysmorphic features. His weight was $14.6 \mathrm{~kg}$. He had shotty cervical lymphadenopathy and a firm, immobile, right upper quadrant abdominal mass. CT scan showed a calcified tumor invading the right kidney and displacing liver, aorta and the inferior vena cava. A spot urine vanilyl mandelic acid was positive. Bone marrow examination confirmed the diagnosis of neuroblastoma stage IV. He was started on chemotherapy and he was doing relatively well 8 months following the diagnosis.

\section{Discussion}

The teratogenic effect of phenytoin has been extensively investigated although its role has not been definitively dissociated from that of other antiepileptic drugs. There is likely a two to three-fold increased risk of malformations and anomalies such as cleft lip and palate, ventricular septal defect, distal digital hypoplasia, other digital anomalies and microcephaly in children exposed to phenytoin in utero. ${ }^{7}$ The rarely seen full-blown "fetal hydantoin syndrome" (FHS) also includes other minor malformations and in some cases mental retardation. ${ }^{8} \mathrm{~A}$ number of single case reports suggest that prenatal phenytoin exposure is associated with an increased incidence of neuroblastoma ${ }^{1-6}$ and other neuroectodermal childhood neoplasms. ${ }^{10-12}$ There

From the Division of Neurology, Ottawa General Hospital (S.A.-S., A.G.) and the Department of Pediatrics, Children's Hospital of Eastern Ontario (E.H.) Received July 15, 1991. Accepted in final form October 24, 1991

Reprint requests to: Dr. A. Guberman, Division of Neurology, Ottawa General Hospital, 501 Smyth Road, Ottawa, Ontario, Canada K1H 8L6 
have been 6 cases of neuroblastoma and three other neuroectodermal tumors associated with FHS reported since 1976 (Table 1). ${ }^{1-6,10-12}$ Seeler et al. have calculated, that purely by chance, it would take approximately 60 years, to generate the three cases of the fetal hydantoin syndrome with neuroblastoma reported within a three-year span prior to $1979 .{ }^{10}$ Additionally, 4 non-neuroectodermal neoplasms were recently reported (1 mesenchymoma, 1 Hodgkins disease, 1 rhabdomyosarcoma and Wilms' tumor), all occurring in dysmorphic children except the rhabdomyosarcoma which occurred in a normal child (Table 2). ${ }^{13-16}$ In 4 of the 12 children with neoplasia exposed to antiepileptic drugs in utero, phenytoin was the only agent involved, while in the other 8 cases, it was used in combination with other drugs (or alcohol).

Our patient represents the first reported case of neuroblastoma in a physically normal child who was exposed to antiepileptic drugs prenatally. Ependymoblastoma is the only other neuroectodermal neoplasm reported in a physically normal child exposed to phenytoin in utero. ${ }^{12}$ This observation suggests that, if phenytoin is oncogenic, the mechanisms involved are possibly separate from those related to its teratogenic effect.

Phenytoin has been linked to benign lymphoid hyperplasia and malignant lymphoma in adults presumably through effects on the immune system. ${ }^{12}$ Experimental studies investigating the oncogenic potential of phenytoin in animals were inconclusive and suffered from methodological flaws. ${ }^{17,18}$ The possible transplacental oncogenicity of phenytoin has not been studied in experimental animals. Epoxides (arene oxides), intermediate metabolites of phenytoin in some patients as well as of carbamazepine have been reported to be oncogenic as well as mutagenic. ${ }^{19,20}$ The ability of arene oxides and their derivatives to bind covalently to RNA and DNA provides a possible molecular

Table 1: Neuroectodermal Tumors Associated with Fetal Exposure to Antiepileptic Drugs

\begin{tabular}{|c|c|c|c|c|c|}
\hline Author & Tumor & $\begin{array}{c}\text { Age at } \\
\text { Diagnosis }\end{array}$ & Sex & Drugs & Anomalies/Malformations \\
\hline Sherman and Roizen ${ }^{1}$ & Neuroblastoma & 1 week & M & phenytoin \& phenobarbital & $\begin{array}{l}\text { Fetal hydantoin syndrome } \\
\text { Hypospadias }\end{array}$ \\
\hline Pendergrass and Hanson ${ }^{2}$ & Neuroblastoma & $3 \mathrm{yr}$ & $\mathrm{F}$ & phenytoin \& phenobarbital & Fetal hydantoin syndrome \\
\hline Ramilo et al. ${ }^{3}$ & Neuroblastoma & $35 \mathrm{mo}$ & $\mathbf{M}$ & $\begin{array}{l}\text { phenytoin } \\
\text { alcohol }\end{array}$ & $\begin{array}{l}\text { Fetal alcohol and hydantoin syndrome } \\
\text { Ventricular septal defect }\end{array}$ \\
\hline Allen et al. ${ }^{4}$ & Neuroblastoma & birth & M & phenytoin \& methylphenobarbital & $\begin{array}{l}\text { Fetal hydantoin syndrome ventricular } \\
\text { septal defect, microcephaly }\end{array}$ \\
\hline Ehrenbard and Chagantirs ${ }^{5}$ & Neuroblastoma & $31 \mathrm{mo}$ & $\mathbf{M}$ & phenytoin & Fetal hydantoin syndrome \\
\hline Koren et al. ${ }^{6}$ & Neuroblastoma & $4 w k s$ & $\mathrm{~F}$ & $\begin{array}{l}\text { phenytoin } \\
\text { nicotine }\end{array}$ & $\begin{array}{l}\text { Brachycephaly } \\
\text { Glabellar hemangioma } \\
\text { Strawberry hemangioma } \\
\text { Clubbing } \\
\text { Distal axial triradius bilaterally }\end{array}$ \\
\hline $\begin{array}{l}\text { Al-Sharnmri et al. } \\
\text { (present case) }\end{array}$ & Neuroblastoma & $30 \mathrm{mo}$ & $\mathbf{M}$ & $\begin{array}{l}\text { phenytoin } \\
\text { carbamazepine }\end{array}$ & None \\
\hline Seeler et al. ${ }^{10}$ & $\begin{array}{l}\text { Ganglioneuroblastoma } \\
\text { of adrenal gland }\end{array}$ & $4 \mathrm{wks}$ & $\mathbf{M}$ & phenytoin & $\begin{array}{l}\text { Fetal alcohol and hydantoin syndrome } \\
\text { Eventration of diaphragm } \\
\text { Ventricular septal defect }\end{array}$ \\
\hline Jimenez et al. ${ }^{11}$ & $\begin{array}{l}\text { Melanotic ectodermal } \\
\text { tumor of cheek }\end{array}$ & $6 \mathrm{mo}$ & M & phenytoin \& phenobarbital & Fetal hydantoin syndrome \\
\hline Lipson and Bale ${ }^{12}$ & Ependymo-blastoma & $28 \mathrm{mo}$ & $\mathrm{F}$ & phenytoin \& methylphenobarbital & $\begin{array}{l}\text { Genetic carrier of ornithine } \\
\text { transcarbamylase deficiency }\end{array}$ \\
\hline
\end{tabular}

Table 2: Non-ectodermal Tumors Associated with Fetal Exposure to Antiepileptic Drugs

\begin{tabular}{|c|c|c|c|c|c|}
\hline Author & Tumor & $\begin{array}{c}\text { Age at } \\
\text { Diagnosis }\end{array}$ & Sex & Drugs & Anomalies/Malformations \\
\hline Blattner et al. ${ }^{13}$ & Mesenchymoma & $18 \mathrm{yr}$ & $\mathrm{F}$ & phenytoin & Cleft lip \& palate \\
\hline Taylor and Myers ${ }^{14}$ & $\begin{array}{l}\text { Extrarenal Wilms' } \\
\text { tumor }\end{array}$ & birth & M & $\begin{array}{l}\text { phenytoin, phenobarbital \& } \\
\text { carbamazepine }\end{array}$ & Fetal hydantoin syndrome \\
\hline Bostrom and Nesbit ${ }^{15}$ & Hodgkins disease & $31 / 2 \mathrm{yr}$ & $\mathrm{F}$ & $\begin{array}{l}\text { phenytoin } \\
\text { alcohol }\end{array}$ & $\begin{array}{l}\text { Fetal hydantoin and fetal alcohol } \\
\text { syndrome }\end{array}$ \\
\hline Sholler et al. ${ }^{16}$ & $\begin{array}{l}\text { Left ventricular } \\
\text { rhabdomyosarcoma }\end{array}$ & $5 \mathrm{yr}$ & $\mathrm{F}$ & phenytoin & None \\
\hline
\end{tabular}


basis for the oncogenicity of these metabolites. ${ }^{21}$ Concurrent carbamazepine therapy in our case may have produced increased concentrations of phenytoin arene oxide metabolites through microsomal enzyme induction. There is no evidence suggesting a genetic link between neuroblastoma and idiopathic epilepsy.

We cannot exclude a chance relationship between prenatal phenytoin exposure and neuroblastoma in this case or even a possible relationship to carbamazepine exposure. Koren et al. have pointed out that, on the basis of their own survey of 189 cases of neuroblastoma and data available from the U.S. Collaborative Perinatal Project, there does not appear to be an increased association between neuroblastoma and phenytoin exposure in developmentally normal children. ${ }^{6}$ Of twenty-eight children diagnosed with neuroblastoma in the Quebec screening project since May, 1989, none were known to have been exposed to phenytoin or other antiepileptic drugs in utero (B. Lemieux, personal communication). However, the accumulating number of case reports of primitive neoplasms, some of them quite rare, in the offspring of mothers taking phenytoin during gestation is worthy of attention.

Offspring of mothers exposed prenatally to phenytoin should be closely examined for both teratogenic and oncogenic effects. Children with the fetal hydantoin syndrome should be carefully examined for neoplasia. A complete gestational drug history should be sought in children with neuroblastoma and other neoplasms. Further evidence should be sought, both prospectively and retrospectively for the oncogenic potential of antiepileptic drug exposure in utero.

\section{ACKNOWLEDGEMENTS}

We would like to thank Mrs. Claire Loyer for her help in the preparation of the manuscript.

\section{REFERENCES}

1. Sherman S, Roizen N. Fetal hydantoin syndrome and neuroblastoma. Lancet 1976; 2: 517.

2. Pendergrass TW, Hanson JW. Fetal hydantoin syndrome and neuroblastoma. Lancet 1976; 2: 150.

3. Ramilo J, Harris VJ. Neuroblastoma in a child with the hydantoin and fetal alcohol syndrome. The radiographic features. $\mathrm{Br} \mathrm{J}$ Radiol, 1979; 52: 993-995.
4. Allen RW Jr, Ogden B, Bentley FL, Jung AL. Fetal hydantoin syndrome, neuroblastoma and hemorrhagic disease in a neonate. JAMA 1980; 244: 1464-1465.

5. Ehrenbard LT, Chagantirs K. Cancer in the fetal hydantoin syndrome. Lancet 1981; 2: 97

6. Koren G, Demitrakoudis D, Weksberg R, et al. Neuroblastoma after prenatal exposure to phenytoin: cause and effect? Teratology 1989; 40: 157-162.

7. Leppik IE. Management of seizures during pregnancy. In: Pedley TA, Meldrum BS, eds. Recent Advances in Epilepsy-4. Edinburgh: Churchill Livingstone 1988; 109-121.

8. Hanson JW, Smith DW. The fetal hydantoin syndrome. J Pediatr 1975; 87: 285-290.

9. Yerby MS. Teratogenicity of antiepileptic drugs. In: Pedley TA, Meldrum BS, eds. Recent Advances in Epilepsy-4. Edinburgh; Churchill Livingstone 1988; 93-107.

10. Seeler RA, Israel JN, Royal JE, et al. Ganglioneuroblastoma and fetal hydantoin syndrome. Pediatrics 1979; 63: 524-527.

11. Jimenez JF, Seibert RW, Char F, Brown RE, Seibert JJ. Melanotic neuroectodermal tumor of infancy and fetal hydantoin syndrome. Am J Pediatr Hematol/Oncol 1981; 3: 9-15.

12. Lipson A, Bale P. Ependymoblastoma associated with prenatal exposure to diphenylhydantoin and methylphenobarbitone Cancer 1985; 55: 1859-1862.

13. Blattner WA, Hensen DE, Young RC, Fraumeni JF Jr. Malignant mesenchymoma and birth defects. JAMA 1977; 238: 334-335.

14. Taylor WF, Myers M, Taylor WR. Extrarenal Wilms' tumor in an infant exposed to intrauterine phenytoin. Lancet 1980; 2: 481482.

15. Bostrom B, Nesbit ME Jr. Hodgkin disease in a child with fetal alcohol-hydantoin syndrome. J Pediatr 1983; 103: 760-762.

16. Sholler GF, Hawker RE, Nunn GR, Bale P, Bergin M. Primary left ventricular rhabdomyosarcoma in a child: noninvasive assessment and successful resection of a rare tumor. J Thorac Cardiovasc Surg 1987; 93: 465-472.

17. Krueger GR, Bedoya VA. Hydantoin-induced lymphadenopathies and lymphomas: experimental studies in mice. Recent Res Cancer Res 1978; 64: 265.

18. Jang JJ, Takahashi M, Furukawa F, et al. Long-term in vivo carcinogenicity study of phenytoin (5-5-Diphenylhydantoin) in F344 rats. Fd Chem Tox 1987; 25: 697-702.

19. Blake DA, Fallinger C. Embryopathic interaction of phenytoin and trichloropropene oxide in mice. Teratology 1976; 13:17A.

20. Nebert DW, Jensen NM. The Ah locus: genetic regulation of the metabolism of carcinogens, drugs and other environmental chemicals by cytochrome P-450 mediated mono-oxygenases. CRC Crit Rev Biochem 1979; 6: 402-437.

21. Jerina DM, Daly JW. Arene oxides: a new aspect of drug metabolism. Science 1974; 185: 573-581. 